\title{
Maasen, Sabine and Sutter, Barbara (eds): On Willing Selves: Neoliberal Politics vis-à-vis the Neuroscientific Challenge
}

\author{
Palgrave MacMillan, Hampshire and New York, 2007, \\ 234 pp. ISBN: 0-230-01343-8
}

\section{Robyn Smith}

Published online: 6 November 2008

(C) The Author(s) 2008. This article is published with open access at Springerlink.com

"On Willing Selves: Neoliberal Politics vis-à-vis the Neuro-scientific Challenge" is a collection of essays culled from a conference called "Willing and Doing" held in Munich early in 2004, which was in turn part of a larger research program entitled, "On the Nature and Culture of Volition." I mention this context at the outset because the title of both the conference and the research program better indicate the substance of the book than does the book's actual title. As it is, only one of the book's nine essays concerns the neurosciences and only two engage with neo-liberal politics in any substantive manner. Most of the essays, however, do concern themselves with 'willing selves,' though interestingly 'willing selves' are not a topic in the one essay on the neurosciences and appear in only one of the two essays on neo-liberal politics. Although they are hailed to do so by the book's title, readers should not approach the book expecting to find sustained engagement with the neurosciences.

The essays in this collection are generally concerned with what the editors term 'self-technologies' (agency, self-determination, responsibility and volition) and also Foucauldian 'technologies of the self', (technologies of the will, disciplinary and governmental practices). Significantly, the notion of 'self-technologies' contains within it concepts that are incompatible with the concepts contained within and necessitated by the notion of 'technologies of the self'. The book is divided into four sections, each of which has an Introduction by the editors. These sections are not divided according to which notion is discussed, either 'self-technologies' or 'technologies of the self,' but rather the sections contain representatives of each and in their Introductions the editors seem intent to show how the concepts of each follow from the other. Further, because engaging with the neurosciences are a stated aim of the book (in the title); the Introductions also invoke relations between the neurosciences and the essays in each section, only to rescind the suggested link by 
the end of the Introduction. For example, in the Introduction to the book, the editors suggest that, the neurosciences currently "stimulate all kinds of initiatives", only to tell us in the very next sentence that these initiatives are "hype, horror and daydream' (Maasen and Sutter, 2007, p. 1). Not only do the Introductions attempt to tie together all the topics listed in the book's title, at times the authors of individual essays were also compelled to throw a line out to either neo-liberal politics or the neurosciences and thereby distract from their topic and sometime contradict their theses and findings. Between attempting to fit together incompatible approaches to the self and subjectivity, while feinting challenges to the neurosciences, read as a whole the book proves disorienting.

There are, however, a few bright pieces of original research and sharp analysis and several pieces that will be useful in classroom settings. I suggest that if readers are interested in the specific topics of the essays found in the book, they might engage with them as individual pieces and disregard the feints and approaches made on the behalf of the collection. Here therefore I will review several individual essays for content.

"Self-Help: The Making of Neosocial Selves in Neoliberal Society" tracks the history of self-help literature as a technology of self-change. The authors argue that the discursive practices and the technologies of self, deployed within the self-help literature, constitute a willing self, that the will is both a vehicle and a target of selfhelp books. The piece relies upon recent governmentality studies of the self-help literature to suggest that self-help literature develops technologies of the self that develop and depend upon concepts of choice, autonomy and freedom and that in self-help literature an individualistic and voluntaristic subject is assumed. The authors conclude that with these notions of choice, autonomy and freedom underpinning their workings, self-help books suggests that it is possible to change your life; you need only desire to do so. The piece therefore is suitable for classes considering 'cultural evolution' or 'genealogies' of mundane rituals and practices that constitute 'technologies of the self' as well as the cultural artifacts created by and with these time- and space-bound notions of the self and the will and the place of each in society.

The essay "Technologies of the Will and Their Christian Roots" by Alois Hahn and Maren Schoch is compelling in its detailed presentation of data and its analysis. The authors suggest that "changing structures of society presuppose different forms of social control and various forms of biographical identities for the constituent populations, and that the history of institutions obliging people to confess can be considered as evidence of this general hypothesis" (Hahn and Schoch, 2007, p. 54). The main part of this essay tracks the development of confession from the early age of Christianity to the Reformation and Counter-Reformation, analyzing "the dimensions of confession as technology of the will," making reference to the work of Norbert Elias and Max Weber (Hahn and Schoch, 2007, p. 55). Hahn and Schoch present a detailed and sophisticated analysis of the development of the technology of confession and the varied consequences of these technologies for the substance of consciousness and selves. The power of their analysis lies in the rendering of the variety of effects of confession. The authors suggest toward the end of the essay that, "the main function of these strategies of finding oneself seems to be not so 
much securing social control, but rather creating meaning: not so much assuming responsibility for sins, but producing happiness ..." (Hahn and Schoh, 2007, p. 71). This is a sharp and worthwhile piece for scholars interested in technologies of the self and histories of the practice of confession and will inspire students with the possibilities of historical methods.

Part Two, "Self and (Socio-) Scientific Knowledge" contains the one essay in the book that deals with the neurosciences, "Governing the Will in a Neurochemical Age" by Nikolas Rose. Rose suggests that recent developments in the neurosciences constitute "a shift in human ontology [that] enables us to be governed in new ways. And it enables us to govern ourselves differently" (Rose, 2007, p. 82). After reviewing brain imaging technology, psychopharmacology and behavioral genomics, Rose concludes by tracking the ways in which these new sciences map onto techniques of governance such as prudentialism, and suggests that the neurosciences allow these techniques and technologies of governance to work at the level of the 'brain and its molecular process,' rather than at the level of the will and its psychological and theological parameters. Rose concludes that governance via molecular processes rather than via psychological process will manifest themselves less as 'normalization' and more as 'correction,' with pharmacological correction allowing individuals to take responsibility for and correct their biochemistry such that they might become and remain 'skilled, prudent and active' selves.

Similarly Mariana Valverde, in her piece, "'Craving' Research: Smart Drugs and the Elusiveness of Desire" considers the way new biochemical research allows for new techniques of governance. Valverde begins by arguing for the recent emergence of a new era of 'targeted governance' and suggests that the development of 'smart drugs' is evidence of the emergence of a 'targeted' medical treatment. Indeed it is suggested that with the development of targeted intervention and its adoption by medical authorities, "we can suspect that the key product of universalist humanist governance (Man himself) is perhaps also fading-as suggested in Foucault's evocative image of the "face drawn in the sand at the edge of the sea" (Valverde, 2007 , p. 168). Valverde suggests that the rise of 'smart drugs' within alcohol abuse treatment effects attempts to change techniques and modes of governance of alcoholism and the alcoholic. With 'smart drugs,' treatment for alcoholism now can be rationalized according to the techniques and strategies of 'targeted governance' rather than through the old discourses and practices of willpower. Valverde concludes, however, that the 'smart drug' approach to alcoholism treatment is unlikely to succeed because "no alcohol receptor has ever been located in the brain" and therefore, it is "very difficult to operationalize alcoholism in brain terms" (Valverde, 2007, p. 184). That is, despite the author's argument at the outset that practices of targeted intervention will erase, from the sands of time, the face of Man, and then her review of targeted treatments of alcoholism, she concludes that these practices by which Man might disappear will not take hold in the space of treatments for alcoholism. This seems then a very literal interpretation of Foucault's image of Man fading as a face drawn in the sand at the edge of the sea. Valverde takes us on a tour of the ways in which the inscription of Man fades through the discourses of targeted intervention and governance, only to suggest that the practices of both alcoholism and its governance and treatment lie elsewhere. While 
Valverde reviews some of the program developments and attempts to govern and treat alcoholism through targeted intervention, she does not consider the interaction of the programs built on this model with the alcoholism and the alcoholics that will not yield to such a model. Perhaps this is where the piece becomes a valuable student resource, as this is a site where a craving for research might develop. According to Valverde, it is because alcoholism is unlikely to yield to a 'smart drug' or, presumably, techniques of 'targeted governance', that alcoholism and drinking conduct are fascinating areas of research for the social scientist.

Finally, the essay "Creating Citizen-Consumers? Public Service Reform and (Un)Willing Selves" was to my mind the strongest in the book. The authors present a wealth of original data and analyze it, for specific points, with creative and imaginative force. The strength of the piece comes not only from the wealth of data but also the focus and specificity of the undertaking. The authors set out to explore "the role of conceptions of the consumer in the reform of public services in the United Kingdom" (Clarke et al., 2007, p. 125). They conclude by considering "the analytical and political significance of unwilling selves as dialogic subjects" (Clarke et al., 2007, p. 125).

The piece suggests that the idea of the consumer has recently come to dominate representations of people who use public and government services, and begins by outlining some of the ways in which the consumer has been represented in recent UK governmental efforts. While the analysis of these representations is undertaken in a governmentality mode, the authors insist that the elaboration of neoliberal politics must be understood in its institutional modes as well as its discursive modes. Further, the authors stress that in analyses of governmentality it is "too readily assumed that discourses translate into practices and that discursively constituted subjections evoke the subjects they seek" (Clarke et al., 2007, p. 140). The authors present data from interviews with public service users to suggest that "uncovering discursive constitution" is not enough to understand the development of governmental institutional practices. They suggest that citizens must mobilize multiple discourses to negotiate social institutions and political practices that might be understood as also occupying an 'everyday knowledge' that is not always already dominated by governmental understandings. Clarke, Newman and Westmorland therefore locate a challenge to neoliberal politics in an 'unruly social field'. This is another piece that will work well for teachers concerned that students encounter good analysis developed from various modes of social research.

Open Access This article is distributed under the terms of the Creative Commons Attribution Noncommercial License which permits any noncommercial use, distribution, and reproduction in any medium, provided the original author(s) and source are credited.

\section{Author Biography}

Robyn Smith studied Sociology at Carleton University. She holds a postdoctoral fellowship from the Social Science and Humanities Research Council of Canada and is currently a postdoctoral fellow at the Max Planck Institute for the History of Science in Berlin. 